O. Awida et al., Practical implementation of fuzzy controller for controlling the CNC spindle motor using PLC, pp. 180 - 198

\title{
PRACTICAL IMPLEMENTATION OF FUZZY CONTROLLER FOR CONTROLLING THE CNC SPINDLE MOTOR USING PLC
}

\author{
O. Awida ${ }^{1, *}$, M. El-Bardini ${ }^{2}$, and N. El-Rabaie ${ }^{3}$ \\ Electrical engineer in $10^{\text {th }}$ of Ramadan (Arab valve company.
}

Faculty of Electronic Eng., Industrial Electronics and Control Dept., Menuf, Menofia, Egypt

Received 9 December 2013; accepted 25 December 2013

\begin{abstract}
The main objective of this paper is to practically designa controller that keepsthe performance of CNC spindle speed.The precisionofthe CNC spindlemotor speed affectsthequality of the product andmachine lifetime. Herebyweapplythe PID, fuzzy and fuzzyPIDcontroller'stypesusing the PLC.The controlled parameter is the CNC spindle motor speed. The system performance was evaluated usingthe three controllers. Results of fuzzy-PID show significant improvement in the performance over a wide range of operating conditions.
\end{abstract}

Keywords:Computer Numerical Controlled (CNC), FuzzyControl,Programmable Logic Controller (PLC), PID controller.

\section{Introduction}

Computer numerical control (CNC) machine tools are now widely used in the manufacturing industry. $\mathrm{CNC}$ is one in which the motions and functions of a machine tool are controlled by means of a program containing coded alphanumeric data. CNC can control the motions of the tool or workpiece, the input parameters such as depth of cut, feed and speed, and the functions such as turning coolant on/off, turning the spindle on/off. CNC is widely used for drill press, lathe, milling machine, sheet-metal press working machine, grinding unit, laser, tube-bending machine etc. [1].

Carrying out a high speed of the spindle motor under load is making the motor unstable, so the production is not finished well and the instability of the spindle speed affects the lifetime of the machine and it may cause damage [2]. For that reason, it is very important to control the spindle motor in (CNC) machine [3]. However, the external disturbances are occurred due to the vibration of high speed. These will influence the performance of a spindle motor. To achieve a robust control against the external disturbances and the model uncertainty of the spindle motor, a fuzzy logic controller is implemented.

Fuzzy logic has rapidly become one of the most successful of today's technologies for developing sophisticated control systems. Fuzzy controllers are more robust than conventional PID controllers because they can cover a much wider range of operating conditions than PID can and can operate with noise and disturbances of different nature. Given the dominance of conventional PID control in industrial applications, it is significant both in theory and in practice if a controller can be found that is capable of outperforming the PID controller with comparative ease of use [4]. The simplest and most usual way to implement a fuzzy controller is to realize it as a computer program on a general-purpose computer. However, a large number of fuzzy control applications

\footnotetext{
* Corresponding author

E-mail address: osama_avc@hotmail.com
} 
181

O. Awida et al., Practical implementation of fuzzy controller for controlling the CNC spindle motor using PLC, pp.180 - 198

require a real-time operation to interface high-speed constraints[5].In order to show the effectiveness and the power of this new approach, the Fuzzy-PID has been implemented on the Simatic S7 -200 PLC to control CNC machine [6, 7]. The results are compared with the conventional PID and fuzzy controller.

The outline of this paper is organized as follows: The description of the system under study is presented in Section 2. The design controllers (fuzzy, PID, fuzzy-PID) by PLC are given in Section 3. Both the practical results(without load -under load) and analysisare presented in Section 4 followed by the conclusions and the relevant references.

\section{System Description}

The main parts of the CNC machine are shownin Fig. 1.It includes the following parts:

\section{- The CNCmachine axes}

The CNC machine includes "X, Y, Z"axes, in which each axis is movingby a stepper motoras shown in Fig.1.

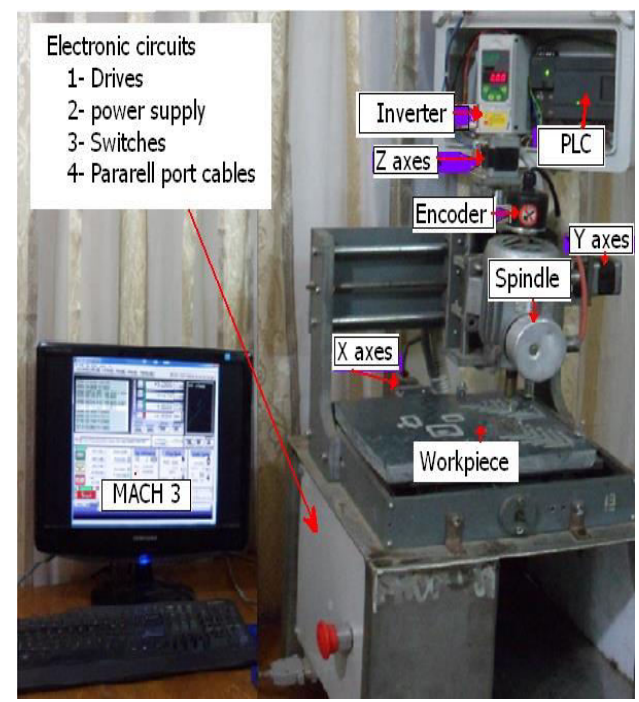

Fig. 1. The CNC machine

\section{- CNC machine interface}

The machine is interfaced with the PC and PLC, in which the PC included software as "Mach 3" to supply the stepper motor drives with desired axis motion. The PLC program responsible about controlling the motion based on suggested controller algorithms.

\section{- Machine spindle}

The spindle motor is an induction motor with a speed of $3200 \mathrm{rpm}$ and the input supply is $220 \mathrm{~V} \mathrm{AC} 3 \mathrm{PH}$, its frequency is $50 \mathrm{HZ}$, and the power is 25 watt, however the speed is changing based on controller of a frequency from 0 to $50 \mathrm{HZ}$ as shown in Fig. 2 [8,9].

Journal of Engineering Sciences, Assiut University, Faculty of Engineering, Vol. 42, No. 1, January, 2014, E-mail address: jes@aun.edu.eg 
O. Awida et al., Practical implementation of fuzzy controller for controlling the CNC spindle motor using PLC, pp.180 - 198

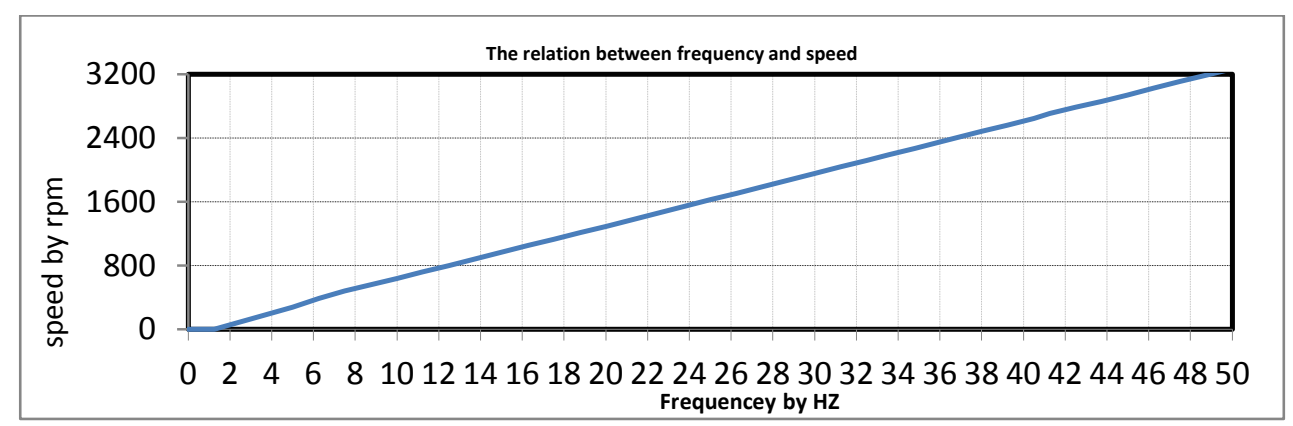

Fig. 2.The calibration curve between frequency and motor

\section{- Thedigital encoder}

The digital encoder is a motor speed measurement device, and the changing in output pulses (0 500 "pulse per second") based on motor speed as shown in Fig. 3.

\section{-The programmable logic controller"PLC"}

The PLC used in this experiment is Siemens S7 200, CPU type is 224XP, 14 inputs / 10 outputs, Boolean execution speed $0.37 \mu \mathrm{s} /$ instruction,it has digitaltoanalogueconvertermodule in the range (0-10) VDC [10, 11].

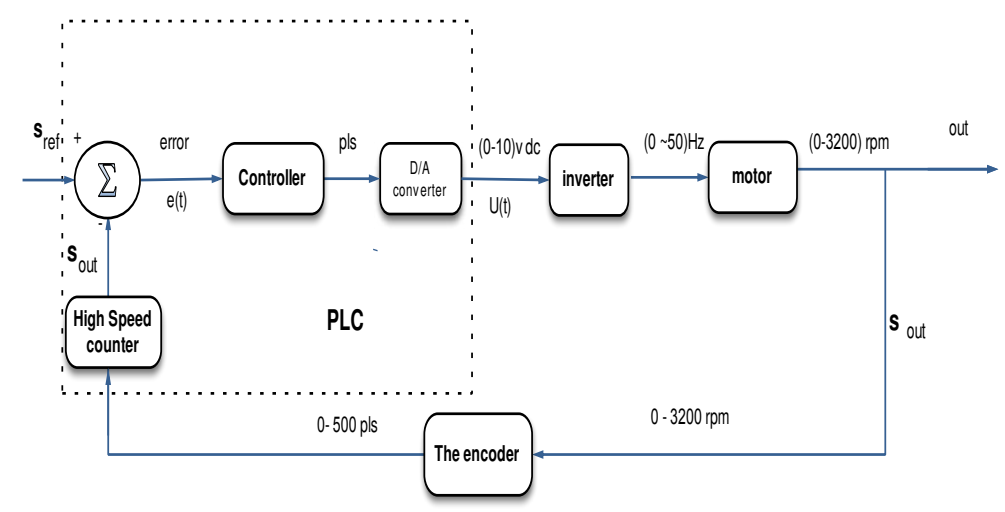

Fig. 3. The control system block diagram.

\section{-AC inverter}

The AC inverterisa device thatconvertsthe out voltagefromPLC analogue module (0$10 \mathrm{VDC})$ tofrequency $(0-50 \mathrm{~Hz})$ then the frequency is:

$$
\mathrm{F}=5 \mathrm{U}(\mathrm{t})
$$

where $\mathrm{F}$ is the frequency by $\mathrm{HZ}$ and $\mathrm{U}(\mathrm{t})$ is controller voltage by volt. Theinputsupplyis 220V AC $1 \mathrm{PH} 50 \mathrm{Hzthe}$ output signalis $220 \mathrm{~V}$ AC 3PHas shown in Fig.4 [9, 12, 13].

Journal of Engineering Sciences, Assiut University, Faculty of Engineering, Vol. 42, No. 1, January, 2014, E-mail address: jes@aun.edu.eg 
O. Awida et al., Practical implementation of fuzzy controller for controlling the CNC spindle motor using PLC, pp.180 - 198

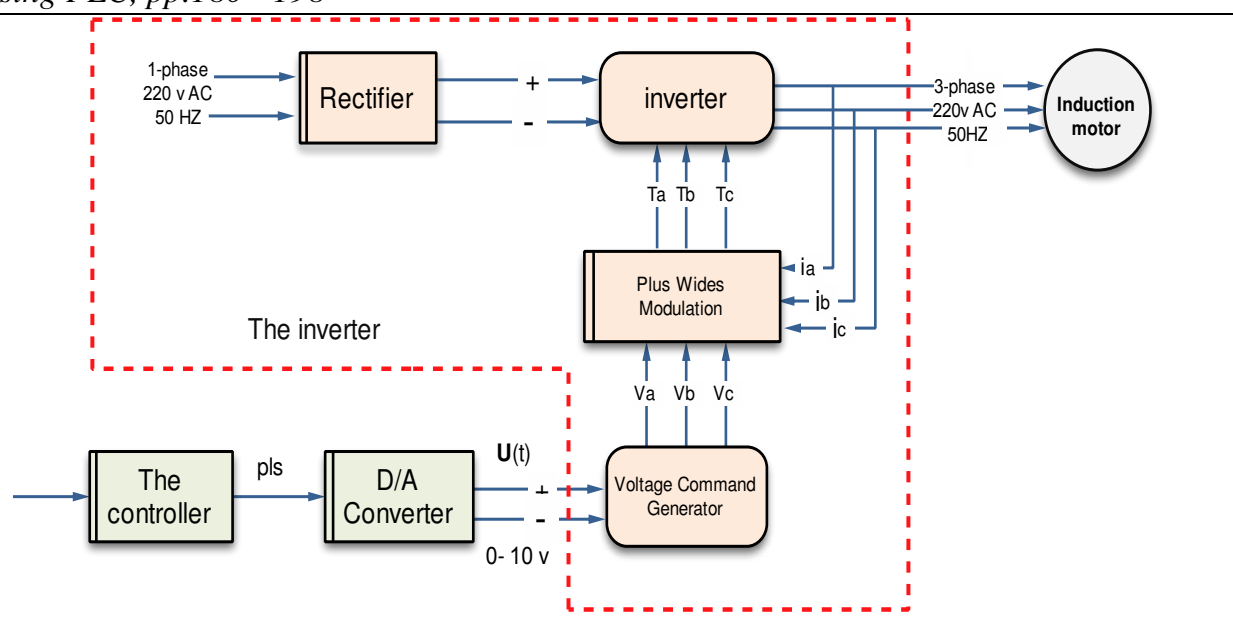

Fig.4.Block diagram for the inverter

\section{PID and Fuzzy Controllers Implementation using PLC}

\subsection{PID controller}

The PID controller regulates the value of the output to drive the error e $(\mathrm{t})$ to zero. A measure of the error is given by the difference between the set-point (the desired operating point), and the process variable (the actual operating point) [14]. The principle of PID control is based upon the following equation that expresses the output, $\mathrm{U}(\mathrm{t})$ as a function of a proportional term, an integral term, and a differential term as follows:

$$
\mathrm{U}(\mathrm{t})=\mathrm{U}(\mathrm{t})_{\text {initial }}+\mathrm{k}_{\mathrm{c}} \mathrm{e}(\mathrm{t})+\mathrm{k}_{\mathrm{c}} \int_{0}^{\mathrm{t}} \mathrm{e}(\mathrm{t}) \mathrm{dt}+\mathrm{k}_{\mathrm{c}} \mathrm{de}(\mathrm{t}) / \mathrm{dt}
$$

where $\mathrm{U}(\mathrm{t})$ is the loop output controller PID as a function of time, $\mathrm{k}_{\mathrm{c}}$ is the loop gain, $e(t)$ is different between the set-point speed $S_{\text {ref }}$ and the actual speed of the induction spindle motor $\mathrm{S}_{\text {out }}$, and $\mathrm{U}(\mathrm{t})_{\text {initial }}$ is the initial value of the loop output [15].

In order to implement this control function in a digital computer, the continuous function must be quantized into periodic samples of the error value with subsequent calculation of the output. The corresponding equation, which is the basis for the digital computer solution, is:

$$
\mathrm{U}(\mathrm{k})=\mathrm{U}(\mathrm{k}-1)+\mathrm{k}_{\mathrm{c}} \mathrm{e}(\mathrm{k})+\mathrm{k}_{\mathrm{c}} \mathrm{T}_{\mathrm{S}} / \mathrm{T}_{\mathrm{I}} \sum_{1}^{\mathrm{k}} \mathrm{e}(\mathrm{k})+\mathrm{k}_{\mathrm{c}} \mathrm{T}_{\mathrm{D}} / \mathrm{T}_{\mathrm{S}}(\mathrm{e}(\mathrm{k})-\mathrm{e}(\mathrm{k}-1))
$$

whereU(k) is the output of the controller of the PID at sample time $k, T_{S}, T_{I}$ and $\mathrm{T}_{\mathrm{D}}$ are the loop sample time, the integral time, and the derivative time respectively.

Since the digital computer must calculate the output value each time the error is sampled beginning with the first sample, it is only necessary to store the previous value of the error and the previous value of the integral term. Because of the repetitive nature

Journal of Engineering Sciences, Assiut University, Faculty of Engineering, Vol. 42, No. 1, January, 2014, E-mail address: jes@aun.edu.eg 
O. Awida et al., Practical implementation of fuzzy controller for controlling the CNC spindle motor using PLC, pp.180 - 198

of the digital computer solution, a simplification in the equation that must be solved at any sample time can be made. The simplified equation is:

$$
\mathrm{U}(\mathrm{k})=\mathrm{U}(\mathrm{k}-1)+\mathrm{k}_{\mathrm{c}} \mathrm{e}(\mathrm{k})+\mathrm{k}_{\mathrm{i}} \sum_{1}^{\mathrm{k}} \mathrm{e}(\mathrm{k})+\mathrm{k}_{\mathrm{d}}(\mathrm{e}(\mathrm{k})-\mathrm{e}(\mathrm{k}-1))
$$

where $\mathrm{k}_{\mathrm{i}}=\mathrm{k}_{\mathrm{c}} \mathrm{T}_{\mathrm{S}} / \mathrm{T}_{\mathrm{I}}$ and $\mathrm{k}_{\mathrm{d}}=\mathrm{k}_{\mathrm{c}} \mathrm{T}_{\mathrm{D}} / \mathrm{T}_{\mathrm{S}}$.

\subsection{Fuzzy control}

In order to establish a proper fuzzy an expert experiences and knowledge is necessary for the membership functions and fuzzy rules [16]. We need to control the speed of the spindle motor by changing the input voltage. When a set-point is defined, if for some reason, the motor runs faster, we need to slow it down by reducing the input voltage. If the motor slows below the set-point, the input voltage must be increased so that the motor speed reaches the set-point, this method is known by fuzzy. The inputs have a set of possible linguistic values $\{\mathrm{NH}, \mathrm{NL}, \mathrm{Z}, \mathrm{PL}, \mathrm{PH}\}, \mathrm{NH}$ stands for Negative High, NL stands for Negative Low, Z stands for Zero, PL stands for Positive LowandPH stands for Positive High.

The output changing of voltage is $\delta \mathrm{U}(\mathrm{k})$, which is added to the reference value in order to eliminate the deviation between the system output and the desired value. It has a set of possible linguistic values $\{$ TSD, SD, NG, SP, TSD, \} where TSD stands for Too Speed Down, SD stands for Speed Down, NG stands for No Change, SP stands for Speed Up andTSP stands for Too Speed Up as shown in Table 1 and Fig. 5.

\section{Table1.}

Fuzzy rule table Change of error $\Delta \mathrm{e}(\mathrm{k})$

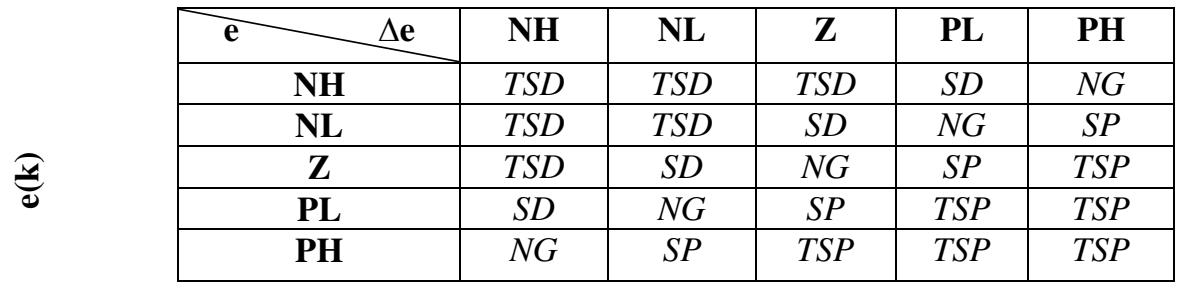

Journal of Engineering Sciences, Assiut University, Faculty of Engineering, Vol. 42, No. 1, January, 2014, E-mail address: jes@aun.edu.eg 
O. Awida et al., Practical implementation of fuzzy controller for controlling the CNC spindle motor using PLC, pp.180 - 198
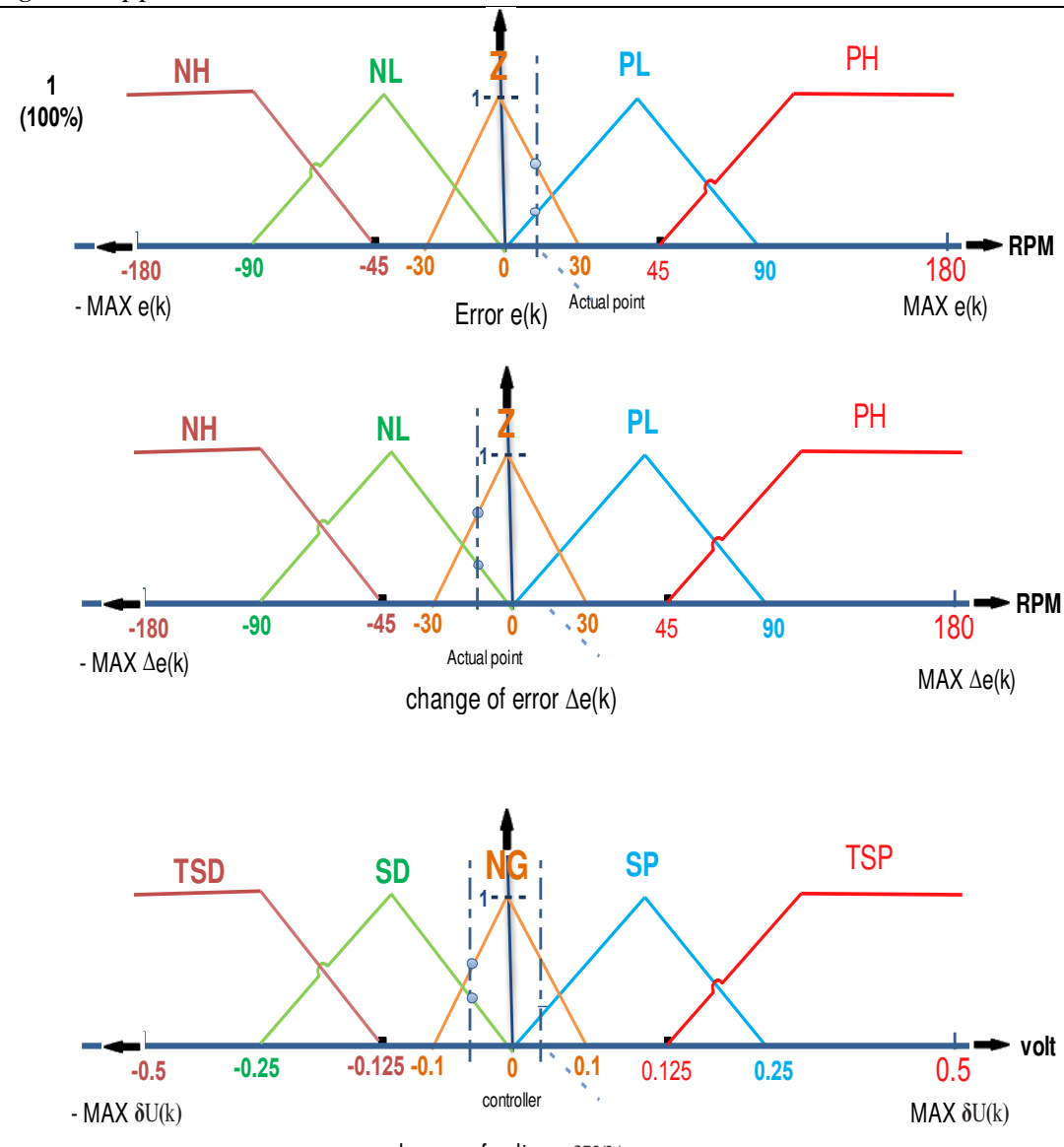

change of voltage $\delta \mathrm{U}(\mathbf{k})$

Fig. 5. Membership functions

\section{- Software design}

A PC and PLC control system is employed to realize CNC spindle motor motion control, which contains a personal computer (PC). The PC sends initialization commands to the PLC in advance, and sends parameter signals to each individual drivers afterwards, such as operation modes, motor speeds and spindle rotation directions. The spindle is driven by the corresponding driver, and feedback the realtime status to the PLC and the PC. The parameters of the spindle motor display on the $\mathrm{PC}$, and the real-time motion is controlled by the PLC.

The S7-200 of micro-programmable logic controllers (Micro PLCs) is used to control the CNC spindle motor, the programming language is the STEP 7-Micro/WIN 32 Ladder Logic (LAD) editor.The Fig. 6 shows the blockdiagram. The print out ofthe first page of the fuzzy ladderprogram is shown in the appendix.

Journal of Engineering Sciences, Assiut University, Faculty of Engineering, Vol. 42, No. 1, January, 2014, E-mail address: jes@aun.edu.eg 
O. Awida et al., Practical implementation of fuzzy controller for controlling the CNC spindle motor using PLC, pp.180 - 198

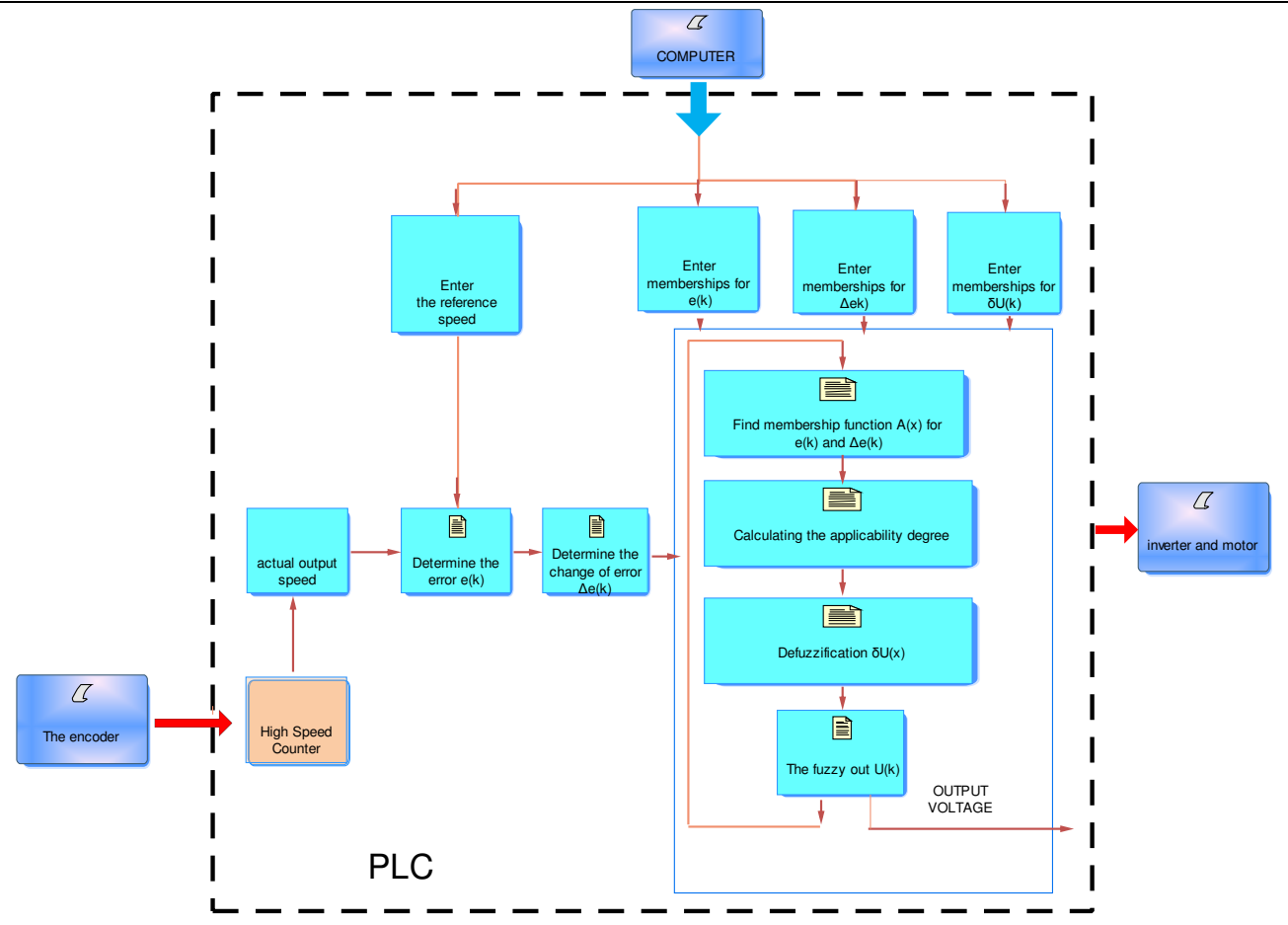

Fig. 6.Block diagram of the ladder program of fuzzy logic controller implementation.

To save the real time reading from PLC to PC (Excel program) by use the Softing S7/S5 OPC Server, The Softing S7 OPC server gives you quick, convenient access to the entire SIMATIC S7 series as well as Siemens WinAC and compatible controllers from other manufactures, the OPC client applications can access the input or output data, flags, timers, counters, etc. of several controllers at once via familiar S7-200.

The following steps show the fuzzy controller designed by PLC:

Step1: Given the reference speed $S_{\text {ref }}$ to the program PLC and save in data register.

Step2: The values of memberships for e $(\mathrm{k}), \Delta \mathrm{e}(\mathrm{k})$ and $\delta \mathrm{U}(\mathrm{k})$ given to program PLC.

Step3:The measurement actual out speed of motor $\mathrm{S}_{\text {out }}$ is save in data register.

Step4: Determine the error $\mathrm{e}(\mathrm{k})$ and $\Delta \mathrm{e}(\mathrm{k})$ as follows:

$$
\begin{aligned}
& \mathrm{e}(\mathrm{k})=\mathrm{S}_{\text {ref }}-\mathrm{S}_{\text {out }} \\
& \Delta \mathrm{e}(\mathrm{k})=\mathrm{e}(\mathrm{k})-\mathrm{e}(\mathrm{k}-1)
\end{aligned}
$$

Journal of Engineering Sciences, Assiut University, Faculty of Engineering, Vol. 42, No. 1, January, 2014,E-mail address: jes@aun.edu.eg 
O. Awida et al., Practical implementation of fuzzy controller for controlling the CNC spindle motor using PLC, pp.180 - 198

Step5: Find the intersection of membership function $\mathrm{A}(\mathrm{x})$ fore $(\mathrm{k})$ and $\Delta \mathrm{e}(\mathrm{k})$

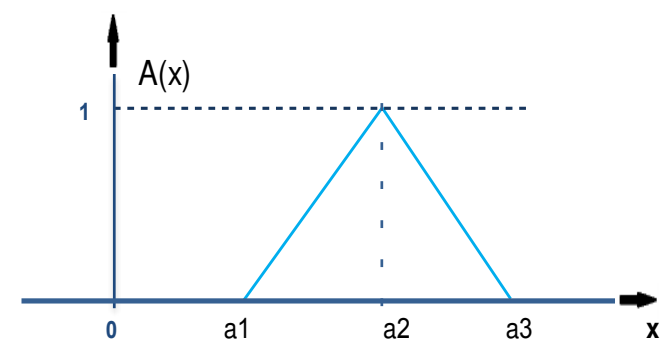

(a)

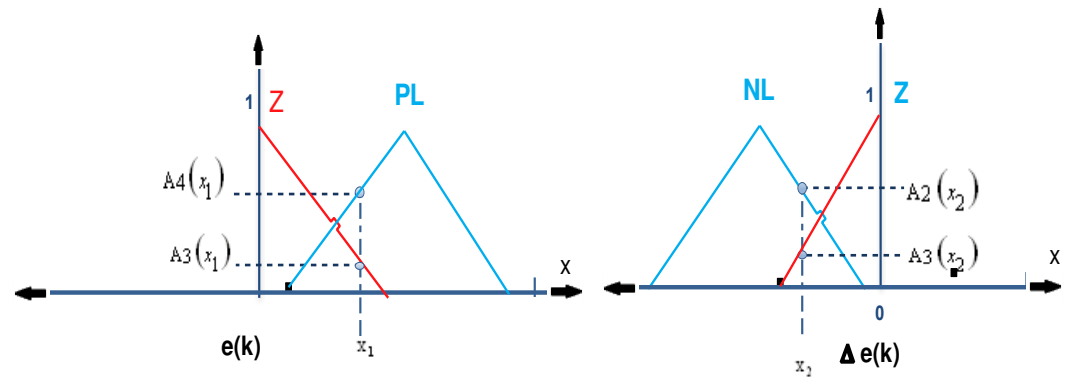

(b)

Fig. 7.Membership function(a) Triangular fuzzy member (b) Applicability degree

The grade of triangular membership function is shownFig.7(a) and defined by [17]:

$$
A(x)= \begin{cases}0, & x<a_{1} \\ \left(x-a_{1}\right) /\left(a_{2}-a_{1}\right), & a_{1} \leq x \leq a_{2} \\ \left(a_{3}-x\right) /\left(a_{3}-a_{2}\right), & a_{2} \leq x \leq a_{3} \\ 0, & x>a_{3}\end{cases}
$$

Step6: Calculating the applicability degree.

At this stage, the degree to which the whole condition part (all the inputs) satisfies the ruleis calculated as showing in Fig.7(b) and the applicability degree here $\operatorname{as} \mu_{\mathrm{kj}}(\mathrm{x}): \mu_{\mathrm{kj}}(\mathrm{x})=A_{k}\left(\mathrm{x}_{1}\right) * A_{j}\left(\mathrm{x}_{2}\right) \quad \ldots . A_{n}\left(\mathrm{x}_{\mathrm{n}}\right)$

Where $x_{i}$ is the value for the $i$ th crisp input, $k$ and $j$ is the number of membership for $\mathrm{e}(\mathrm{k}), \Delta \mathrm{e}(\mathrm{k})$ respect, $\mathrm{A}_{\mathrm{n}}\left(\mathrm{x}_{\mathrm{n}}\right)$ is the members hip function for the corresponding linguistic value for the corresponding input [17].

Journal of Engineering Sciences, Assiut University, Faculty of Engineering, Vol. 42, No. 1, January, 2014, E-mail address: jes@aun.edu.eg 
O. Awida et al., Practical implementation of fuzzy controller for controlling the CNC spindle motor using PLC, pp.180 - 198

Step7:Apply fuzzy rules.

Let the measured $\mathrm{e}(\mathrm{k})$ and $\Delta e(k)$ be as shown in the figure above. We see that this will fire four rules:

IF e(k) is $Z$ and $\triangle e(k)$ is NL THEN $\delta U(k)$ is $S D$ " $\mu_{32} "$.

IF e $(k)$ is PL and $\triangle e(k)$ is NL THEN $\delta U(k)$ is $N G$ " $\mu_{42} "$ ".

IF e $(k)$ is $Z$ and $\triangle e(k)$ is $Z$ THEN $\delta U(k)$ is $N G$ " $\mu_{33} "$.

IF e $(k)$ is $P L$ and $\triangle e(k)$ is $Z$ THEN $\delta U(k)$ is $S P " \mu_{43} "$.

\section{Table 2.}

Fuzzy rule table

\section{$\Delta \mathbf{e}(\mathbf{k})$}

\begin{tabular}{|c|c|c|c|c|c|}
\hline $\mathbf{e} \Delta \mathbf{e}$ & $\mathbf{N H}$ & $\mathbf{N L}$ & $\mathbf{Z}$ & $\mathbf{P L}$ & $\mathbf{P H}$ \\
\hline $\mathbf{N H}$ & $\mu_{11}$ & $\mu_{12}$ & $\mu_{13}$ & $\mu_{14}$ & $\mu_{15}$ \\
\hline $\mathbf{N L}$ & $\mu_{21}$ & $\mu_{22}$ & $\mu_{23}$ & $\mu_{24}$ & $\mu_{25}$ \\
\hline $\mathbf{Z}$ & $\mu_{31}$ & $\mu_{32}$ & $\mu_{33}$ & $\mu_{34}$ & $\mu_{35}$ \\
\hline $\mathbf{P L}$ & $\mu_{41}$ & $\mu_{42}$ & $\mu_{43}$ & $\mu_{44}$ & $\mu_{45}$ \\
\hline $\mathbf{P H}$ & $\mu_{51}$ & $\mu_{52}$ & $\mu_{53}$ & $\mu_{54}$ & $\mu_{55}$ \\
\hline
\end{tabular}

From eq. (8) then

$$
\begin{array}{ll}
\mu_{32}=A_{3}\left(\mathrm{x}_{1}\right) & * A_{2}\left(\mathrm{x}_{2}\right) \\
\mu_{42}=A_{4}\left(\mathrm{x}_{1}\right) & * A_{2}\left(\mathrm{x}_{2}\right) \\
\mu_{33}=A_{3}\left(\mathrm{x}_{1}\right) & * A_{3}\left(\mathrm{x}_{2}\right) \\
\mu_{43}=A_{4}\left(\mathrm{x}_{1}\right) & * A_{3}\left(\mathrm{x}_{2}\right)
\end{array}
$$

\section{Step8:Defuzzification}

A defuzzifier compiles the information provided by each of the rules and makes a decision from this basis. The most commonly used method is the Center of Area (COA). It generates the center of gravity of the possibility distribution of $\delta \mathrm{U}(\mathrm{x})$ as follows:

$$
\delta \mathrm{U}(\mathrm{x})=\frac{\sum_{k=1}^{n} \mathrm{x}_{\mathrm{k}} \Pi_{j=1}^{n} \mu_{\mathrm{kj}}(\mathrm{x})}{\sum_{k=1}^{n} \Pi_{j=1}^{n} \mu_{\mathrm{kj}}(\mathrm{x})}
$$

where $\mathrm{n}$ is the number of quantization levels of a universe $\mathrm{U}$ and $\mathrm{x}_{\mathrm{k}}$ is the point in thek $^{\text {th }}$ quantization level in a universe $\mathrm{U}$ at which $\mu(\mathrm{x})$ is its maximum value $\mu_{\mathrm{kj}}(\mathrm{x})$ [17].

From the above formula, then $\delta \mathrm{U}(\mathrm{x})$ is:

Journal of Engineering Sciences, Assiut University, Faculty of Engineering, Vol. 42, No. 1, January, 2014, E-mail address: jes@aun.edu.eg 
O. Awida et al., Practical implementation of fuzzy controller for controlling the CNC spindle motor using PLC, pp.180 - 198

$$
\delta \mathrm{U}(\mathrm{x})=\frac{\mathrm{SD} * \mu_{32}+\mathrm{NG} * \mu_{42}+\mathrm{NG} * \mu_{33}+\mathrm{SP} * \mu_{43}}{\mu_{32}+\mu_{42}+\mu_{32}+\mu_{33}+\mu_{43}}
$$

Step9:The fuzzy out

The control action out $\mathrm{U}(\mathrm{k})$ can be determined as:

$\mathrm{U}(\mathrm{k})=\mathrm{U}_{\mathrm{cal}}+\delta \mathrm{U}(\mathrm{x})$

where $\mathrm{U}_{\mathrm{cal}}$ is the calibrated voltage of the reference speed $\mathrm{S}_{\mathrm{ref}}$.

\subsection{Fuzzy-PID controller}

In order to achieve high performance under specified operating condition a combination between fuzzy controller and conventional PID controlleris proposed as shown as Fig. 8, in which the fuzzy controller achieves improvement in the transient response and the PID controller impress the performance in the steady state [18-22]. The controller that is given in eq. (10) is modified to be:

$\mathrm{U}(\mathrm{k})=\mathrm{U} 1(\mathrm{k})+\delta \mathrm{U}(\mathrm{x})$

WhereU1 $(\mathrm{k})$ is the control signal of conventional PID controller and $\delta \mathrm{U}(\mathrm{x})$ is defined as in eq. (9).

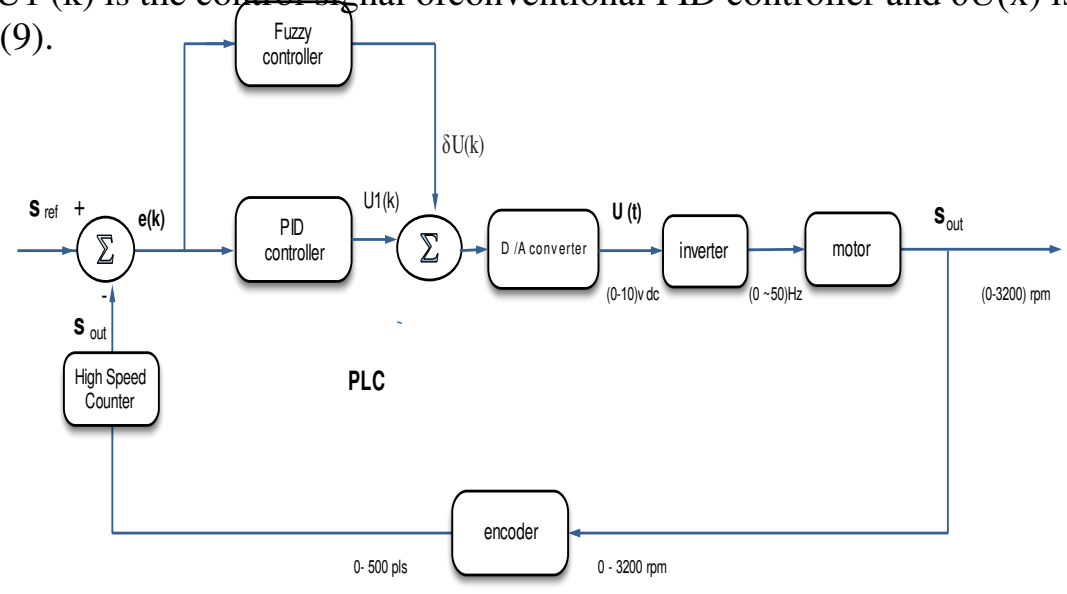

Fig. 8. Fuzzy-PID controller

\section{Practical Results}

In this section,the controller is tested in two cases:firstly, incase starting without load, secondly incase the controller systems are under load. The RMS error is used as a measure for the controller's performance as:

$$
\mathrm{RMS}=\sqrt{\frac{1}{\mathrm{~N}} \sum_{\mathrm{k}=1}^{\mathrm{N}}\left(\mathrm{S}_{\mathrm{ref}}(\mathrm{k})-\mathrm{S}_{\mathrm{out}}(\mathrm{k})\right)^{2}}
$$

Where $\mathrm{N}$ is the number of the sample points, $\mathrm{S}_{\mathrm{ref}}(\mathrm{k})$ is the speed set-point and $\mathrm{S}_{\text {out }}(\mathrm{k})$ is the actual output speed [12].

Journal of Engineering Sciences, Assiut University, Faculty of Engineering, Vol. 42, No. 1, January, 2014, E-mail address: jes@aun.edu.eg 
O. Awida et al., Practical implementation of fuzzy controller for controlling the CNC spindle motor using PLC, pp.180 - 198

4.1.System response without load

In the beginning we indicate four references for speed set-point(speed $0 \mathrm{rpm}, 1000$ rpm,1700 rpm and $2420 \mathrm{rpm}$ ), then we implementthe three controller systems PID, fuzzy and fuzzy-PID as shown in Fig. 9.

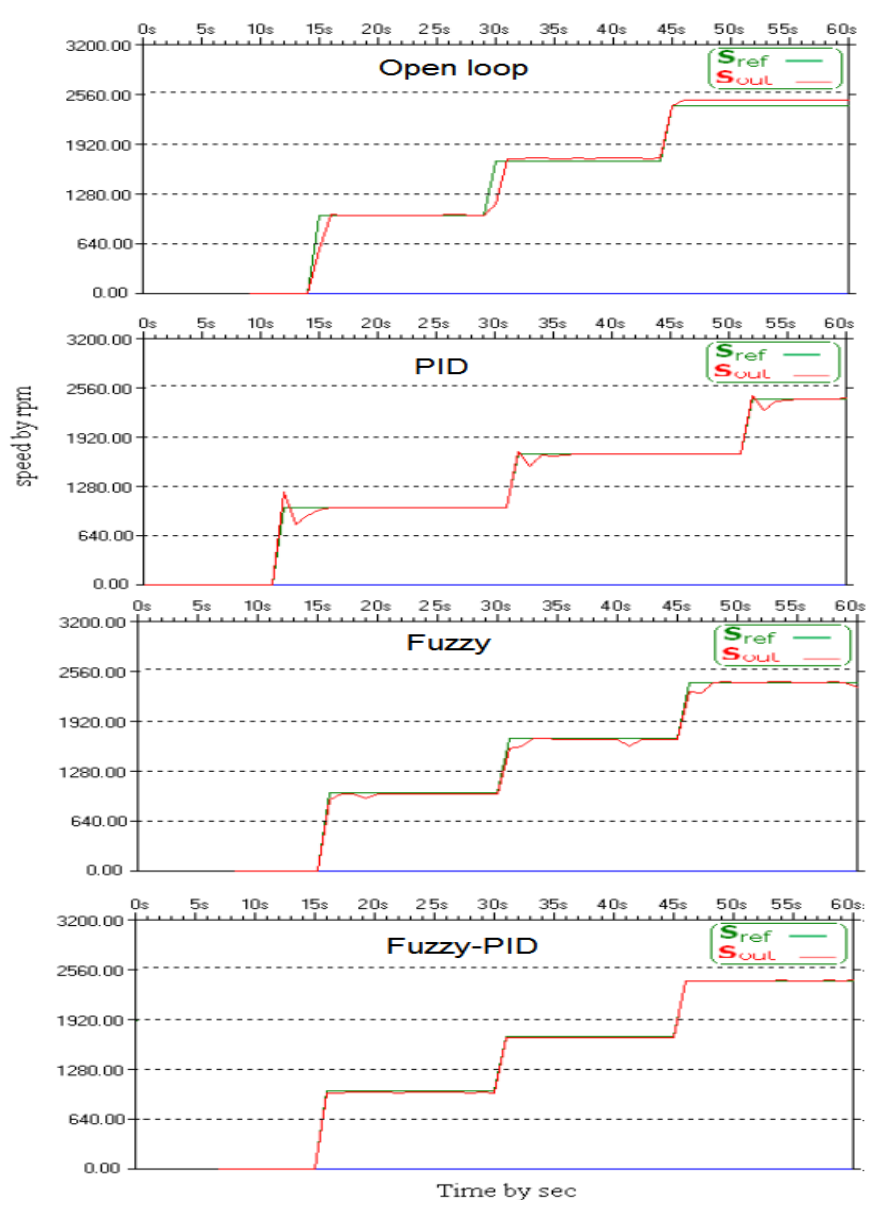

Fig. 9. Controllers results without load between the speed set-point $S_{\text {ref }}$ and the actual output speed $\mathrm{S}_{\text {out }}$.

Fig. 9 shows the response of the CNC spindle motor without load for the PID, the fuzzy and the fuzzy -PID controllers under reference changes. It is clear that the PID controller has good results in steady state but there is an overshoot occurs when the setpoint changes from a step to another. The fuzzy controller has good results in transient state term, there is no overshoot in the output when the set-point changes from a step to the other but there is a steadystate error. The fuzzy -PID controller has good results in the transient and in the steady state in which the output of the system is matched with variable set points.

Journal of Engineering Sciences, Assiut University, Faculty of Engineering, Vol. 42, No. 1, January, 2014, E-mail address: jes@aun.edu.eg 
191

O. Awida et al., Practical implementation of fuzzy controller for controlling the CNC spindle motor using PLC, pp.180 - 198

4.2. Control systemunderload

The three controller systems are tested using different loads with different depths of cutting at $0 \mathrm{~mm}, 2 \mathrm{~mm}, 4 \mathrm{~mm}$ and $6 \mathrm{~mm}$, the processed material is PVC (PolyVinyl Chloride) material, and the cutting tool's type is Carbide flat withan end mill diameter $6 \mathrm{~mm}$.

\section{Case 1:}

The controller systems are tested using four references of speed set-points (speed 0 rpm, $1000 \mathrm{rpm}, 1700 \mathrm{rpm}$ and $2420 \mathrm{rpm}$ ) with one depth of cutting at $4 \mathrm{~mm}$.

Fig. 10 shows the open loop, PID, fuzzy and fuzzy -PID controller's responses of the $\mathrm{CNC}$ spindle motor under change of $S_{\text {ref }}$ with fixed cutting depth $4 \mathrm{~mm}$. In the case of open loop, the motor is stopped, in which the PID controller causes high overshot and fuzzy controller causes high error in the steady state, in which the fuzzy-PID controller is better.

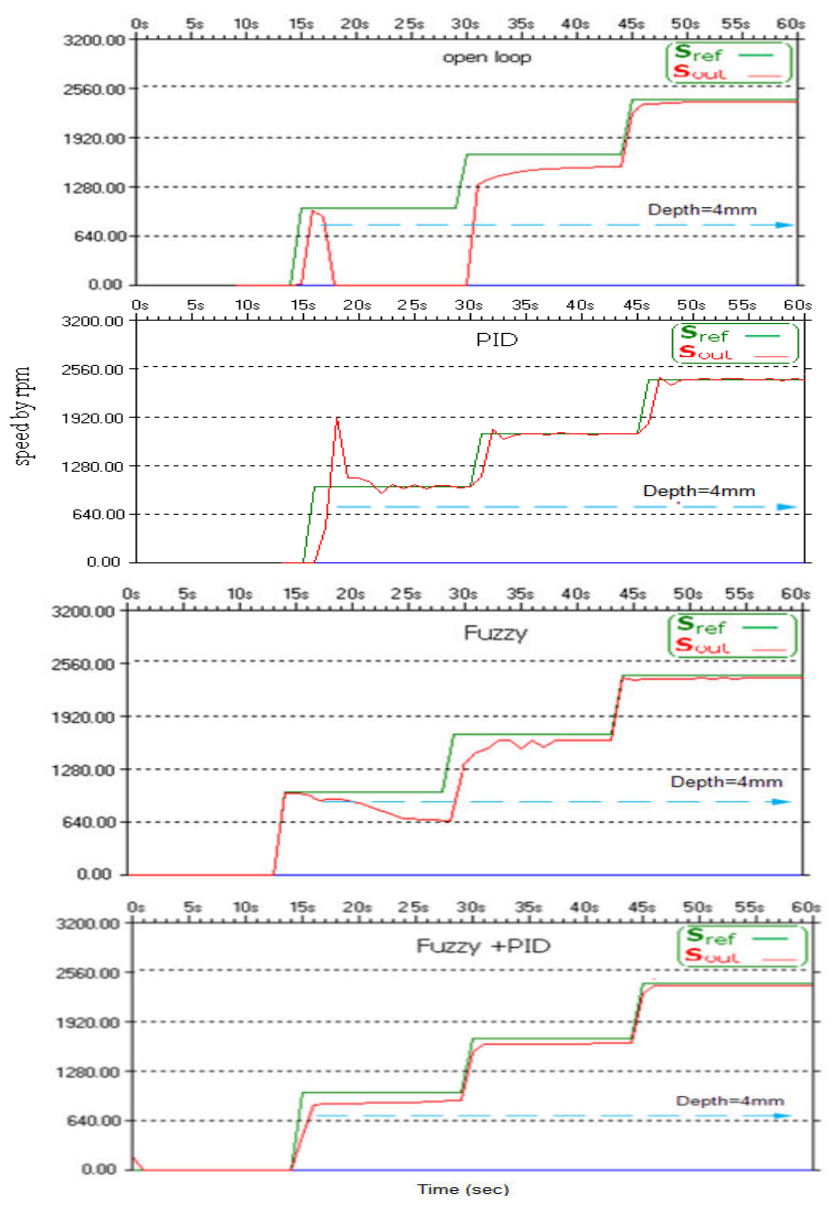

Fig. 10. The controller systems results under load (depth of cutting at $4 \mathrm{~mm}$ )

Journal of Engineering Sciences, Assiut University, Faculty of Engineering, Vol. 42, No. 1, January, 2014,E-mail address: jes@aun.edu.eg 
O. Awida et al., Practical implementation of fuzzy controller for controlling the CNC spindle motor using PLC, pp.180 - 198

\section{Case 2:}

The controller systems are tested using four references of speed set-points (speed 0 rpm, $1000 \mathrm{rpm}, 1700 \mathrm{rpm}$ and $2420 \mathrm{rpm}$ ) with different depths of cutting at $0 \mathrm{~mm}$, $2 \mathrm{~mm}, 4 \mathrm{~mm}$ and $6 \mathrm{~mm}$.

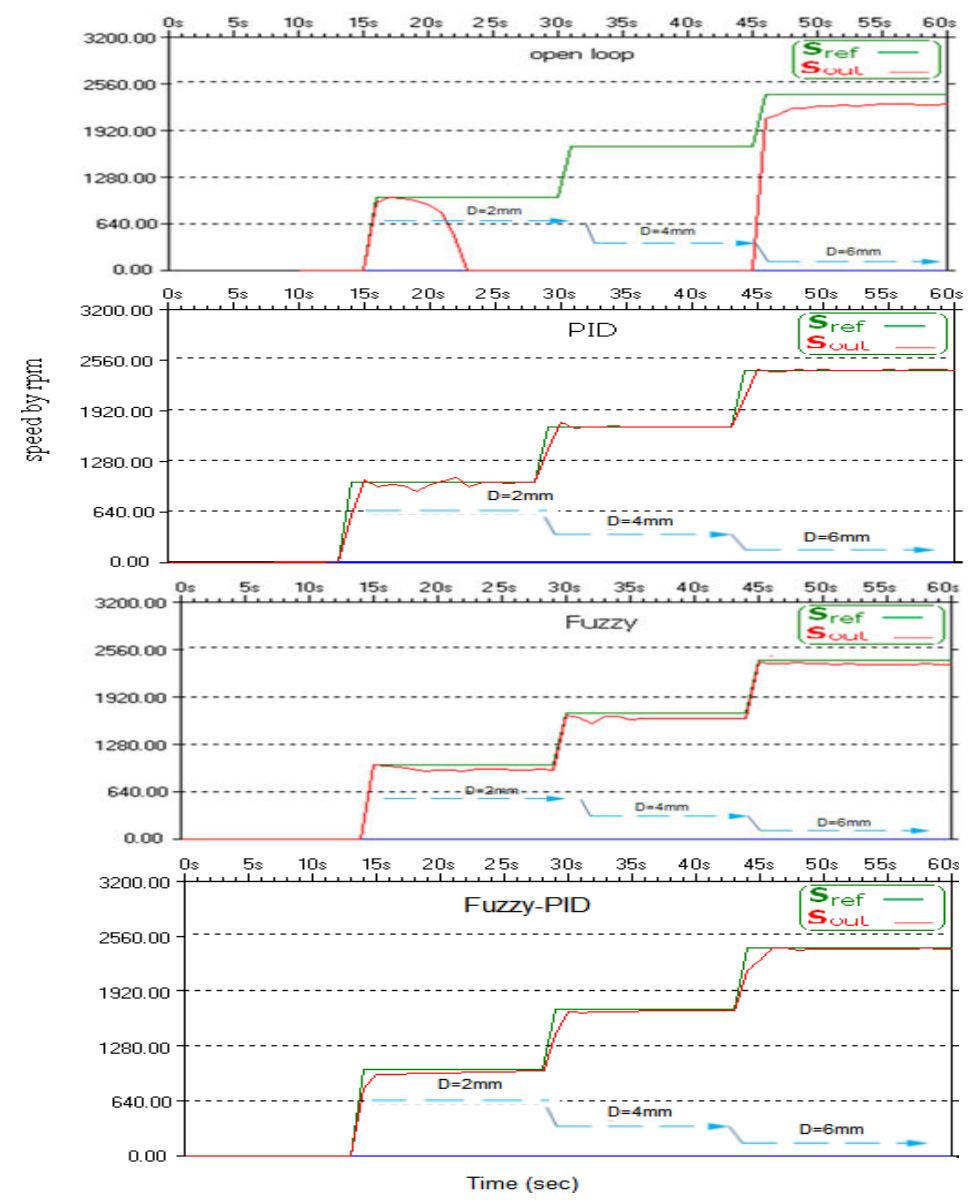

Fig. 11. The controller systems results under load (depths of cutting at 0, 2, 4 and $6 \mathrm{~mm}$ )

Fig. 11 shows the system controller's responses of the CNC spindle motor under change of $\mathrm{S}_{\text {ref }}$ with change of cutting depth. Which in the case of the open loop, the motor is stopped at speed is $1000 \mathrm{rpm}$ with cutting depth is $2 \mathrm{~mm}$ in which the fuzzy PID solves this problem.

Journal of Engineering Sciences, Assiut University, Faculty of Engineering, Vol. 42, No. 1, January, 2014, E-mail address: jes@aun.edu.eg 
193

O. Awida et al., Practical implementation of fuzzy controller for controlling the CNC spindle motor using PLC, pp.180 - 198

\section{Case 3}

The controller systems are tested using one reference of speed set-point (2420 rpm) with different depths of cutting at $0 \mathrm{~mm}, 4 \mathrm{~mm}$ and $6 \mathrm{~mm}$.
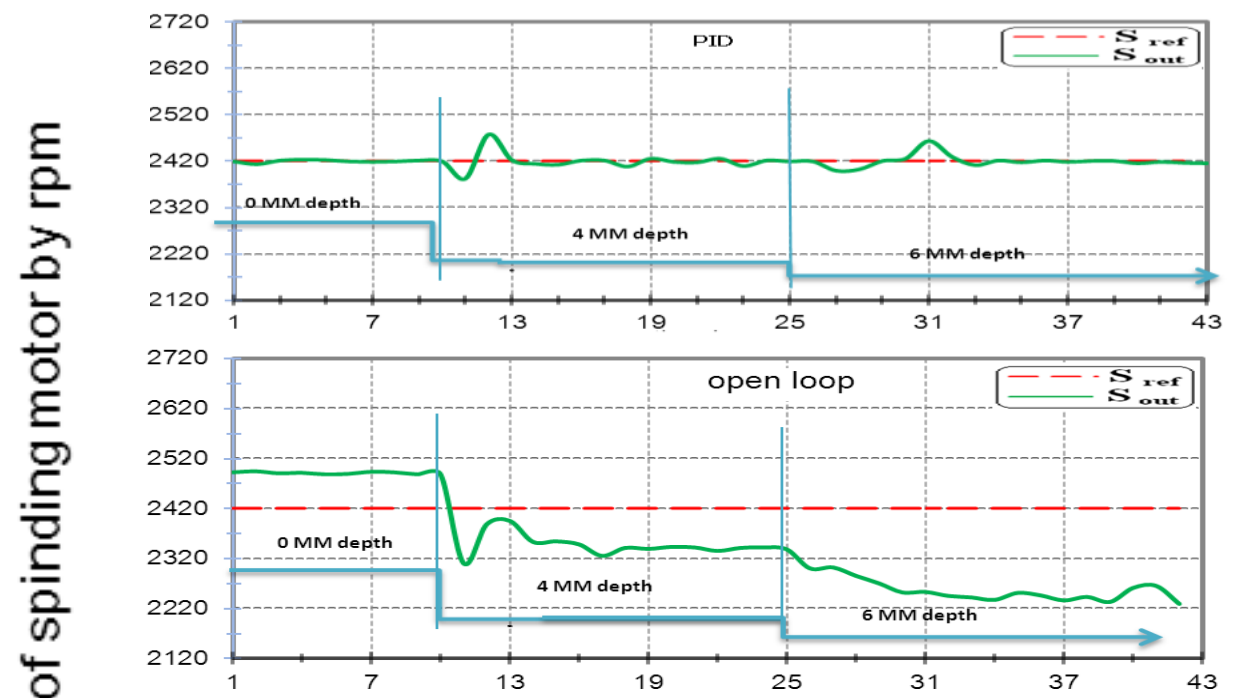

웅
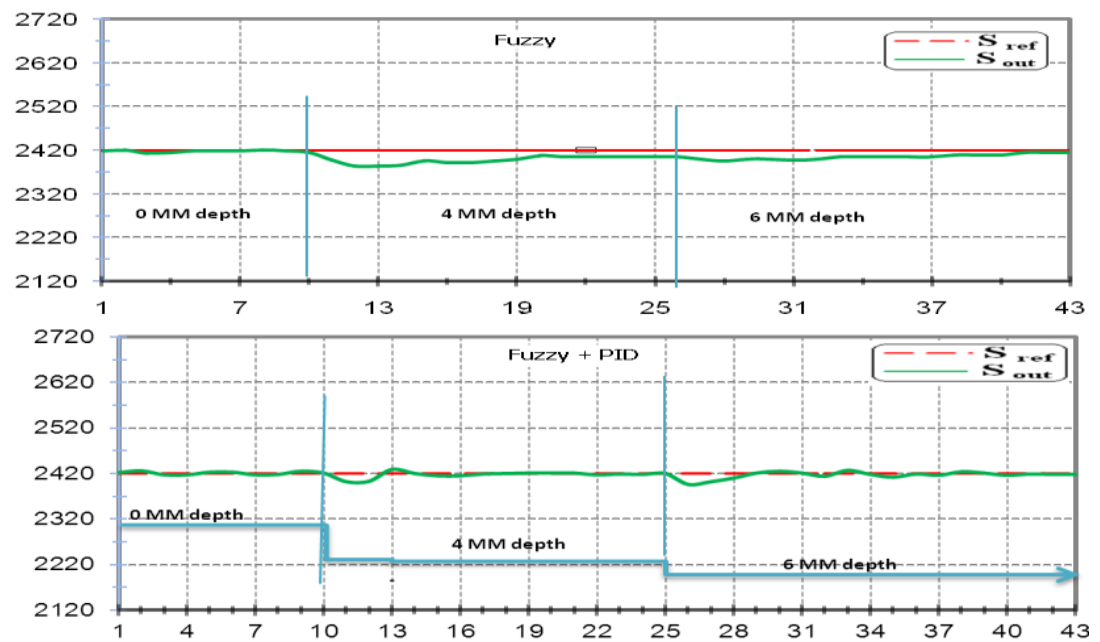

(a) Time $(\mathrm{Sec})$

Journal of Engineering Sciences, Assiut University, Faculty of Engineering, Vol. 42, No. 1, January, 2014, E-mail address: jes@aun.edu.eg 
O. Awida et al., Practical implementation of fuzzy controller for controlling the CNC spindle motor using PLC, pp.180 - 198
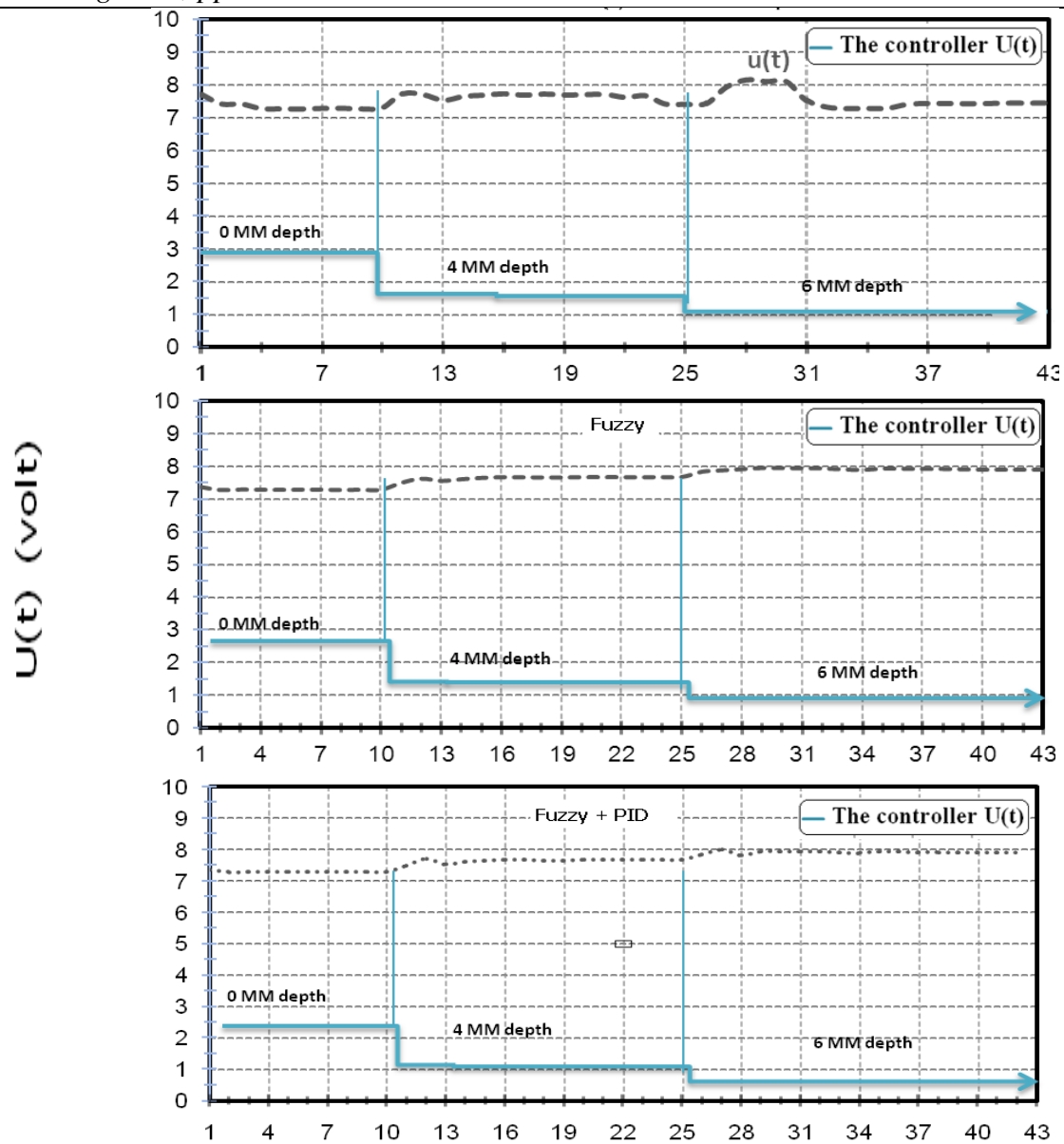

(b) Time (sec)

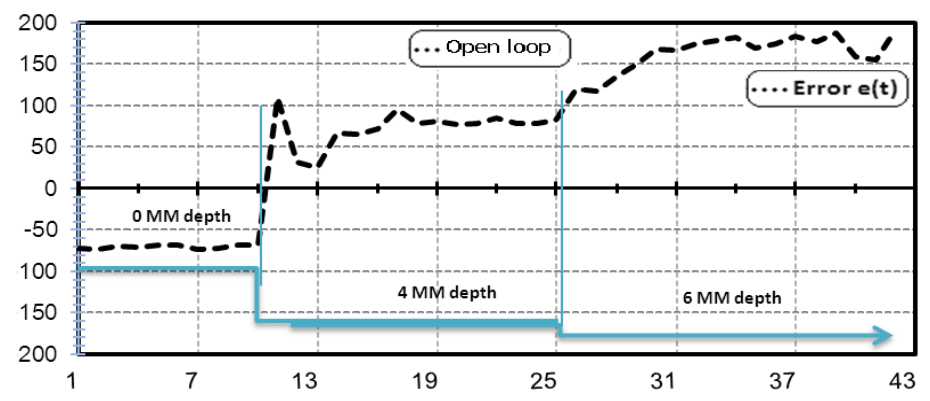

Journal of Engineering Sciences, Assiut University, Faculty of Engineering, Vol. 42, No. 1, January, 2014, E-mail address: jes@aun.edu.eg 
O. Awida et al., Practical implementation of fuzzy controller for controlling the CNC spindle motor using PLC, pp.180 - 198
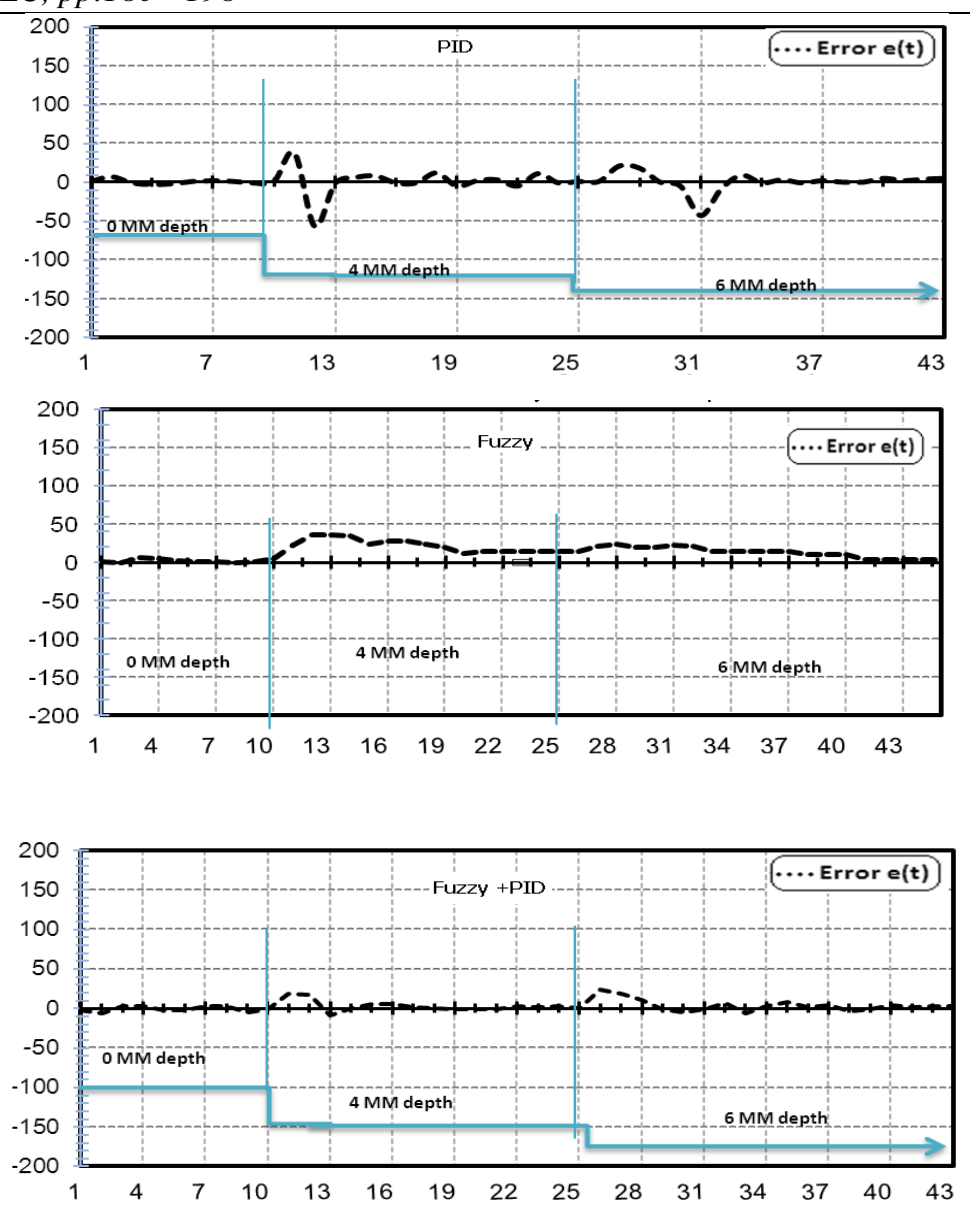

(c) Time (sec)

Fig. 12. Controller resultsundera load at depths 0,4 and $6 \mathrm{~mm}$ (a) the speed setpoint $S_{\text {ref }}$ and the actual output speed $S_{\text {out }}$ (b) The controller signal U (t) (c) The error e $(\mathrm{t})$

Fig. 12 shows the open loop, PID, fuzzy and fuzzy -PID controller's responses of the CNC spindle motor under cutting depth changes. In the case of open loop, the RMS = $165.5 \mathrm{rpm}$ andthe $\mathrm{E} \max (\mathrm{MAX}$ error $)=(\max$ error/set-point $) \%$ is $7.89 \%$. The PID parameters $\mathrm{k}_{\mathrm{c}}=0.9, \mathrm{k}_{\mathrm{i}}=0.1$ and $\mathrm{k}_{\mathrm{d}}=0.001$ are tuned using auto tuning algorithm of PID ladder block s7 200, the details of who using this blockis given [15]. The PID controller possesses good results in the steady state, where the actual output close to the desired output but there is an overshoot when the cutting depth changes from a step to another.

It is clear that the fuzzy controller has good results in the transient, and there is no overshoot in the output when the cutting depth changes from a step to another but it

Journal of Engineering Sciences, Assiut University, Faculty of Engineering, Vol. 42, No. 1, January, 2014, E-mail address: jes@aun.edu.eg 
O. Awida et al., Practical implementation of fuzzy controller for controlling the CNC spindle motor using PLC, pp.180 - 198

results in a steady state error. The fuzzy - PID controller possess good results in the transient and in the steady state, the output of the system under different cutting depths are almost the same to the desired output which the RMS decrease to $8.3 \mathrm{rpm}$ and MAX error (E max) is $0.99 \%$, as shown in Fig. 13. The RMS and MAX error (E max) are indicated in Table 3.

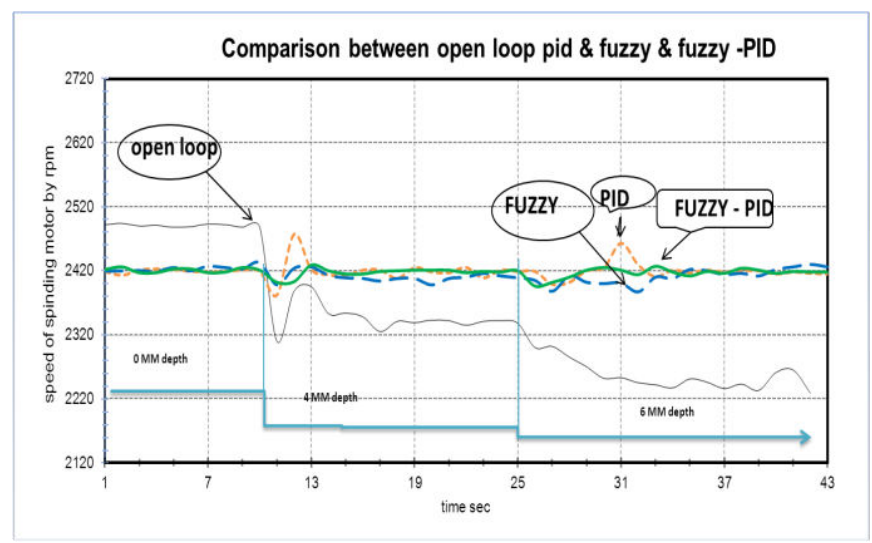

Fig.13.The results ofopen loop, PID, fuzzy and fuzzy-PID controller under load at depths 0,4 and $6 \mathrm{~mm}$

\section{Table 3.}

Comparison between different types of controllersunderload.

\begin{tabular}{|c|c|c|c|c|c|c|c|c|c|c|c|c|}
\hline \multirow{2}{*}{$\begin{array}{l}\text { speed } \\
2420 \\
\text { rpm }\end{array}$} & \multicolumn{4}{|c|}{ Cutting depth $=0 \mathrm{~mm}$} & \multicolumn{4}{|c|}{ Cutting depth $=4 \mathrm{~mm}$} & \multicolumn{4}{|c|}{ Cutting depth $=6 \mathrm{~mm}$} \\
\hline & $\begin{array}{l}\text { Open } \\
\text { loop }\end{array}$ & PID & fuzzy & $\begin{array}{l}\text { Fuzzy- } \\
\text { PID }\end{array}$ & $\begin{array}{l}\text { Open } \\
\text { loop }\end{array}$ & PID & Fuzzy & $\begin{array}{l}\text { Fuzzy- } \\
\text { PID }\end{array}$ & $\begin{array}{l}\text { Open } \\
\text { loop }\end{array}$ & PID & fuzzy & $\begin{array}{l}\text { Fuzzy- } \\
\text { PID }\end{array}$ \\
\hline $\begin{array}{l}\text { RMS } \\
\text { (rpm) }\end{array}$ & 70.53 & 2.68 & 5.2 & 3.39 & 76.76 & 17.9 & 12.6 & 6.76 & 165.5 & 13 & 14.95 & 8.3 \\
\hline$|\mathrm{Emax}| \%$ & 3.06 & 0.29 & 0.29 & 0.25 & 4.54 & 2.36 & 0.91 & 0.74 & 7.89 & 1.78 & 1.36 & 0.99 \\
\hline
\end{tabular}

\section{Conclusions}

Inthispaper,thespeedofaspindlemotorinaCNCmachineiscontrolledexperimentally by means of three controllers, PID, fuzzy and fuzzy-PID. The system performance was evaluated using the three controllers under different depths, $\mathbf{0 m m}, \mathbf{4} \mathbf{m m}$ and $\mathbf{6 m m}$. The resultsof the fuzzy-PID controller shows good and significant improvement in the performance over a wide range of operating conditions.

\section{References}

[1] C. W. de Silva, "Mechatronic Systems: Devices, Design, Control, Operation and Monitoring," CRC Press (Taylor \& Francis Group), 2008.

[2] K. B. Jin, T. Y. Doh, J. R. Ryoo and M. J. Chung, "Robust Direct Seek Control for HighSpeed Rotation Optical Disk Drives," IEEE Trans. on Consumer Electronics, vol. 44, Issue. 4, pp. 1273-1283, November 1998.

Journal of Engineering Sciences, Assiut University, Faculty of Engineering, Vol. 42, No. 1, January, 2014,E-mail address: jes@aun.edu.eg 
O. Awida et al., Practical implementation of fuzzy controller for controlling the CNC spindle motor using PLC, pp.180 - 198

[3]Q.Zhanga, S. Lia, and J.Guo, "Smooth Time-optimal Tool Trajectory Ggeneration for CNC Manufacturing Systems," Journal of Manufacturing Systems, vol. 31, Issue 3, pp. 280-287, July 2012.

[4] H. Ying, "Fuzzy Control and Modeling, Analytical Foundations and Applications," USA: Institute of Electrical and Electronic Engineers Inc., 2000.

[5]M. Hassan and M. F. Sharif, "Design of FPGA Based PID-like Fuzzy Controller for Industrial Applications,” IAENG International Journal of Computer Science, vol.34, no. 2, IJCS_34_2005.

[6] N. Buyurgan, C. Saygin, "Application of the Analytical Hierarchy Process for Real-time Scheduling and Part Routing in Advanced Manufacturing Systems," Journal of Manufacturing Systems, vol. 27, Issue 3, pp. 101-110, July 2008.

[7] O. Karasakal, E. Yesil, M. Guzelkaya and I. Eksin, "Implementation of A new Self-tuning Fuzzy PID Controller on PLC," Turkish Journal of Electrical Engineering, vol. 13, no. 2, pp. 277-286, 2005.

[8]R. Arulmozhiyal and K. Baskaran, "Speed Control of Induction Motor using Fuzzy PI and Optimized using GA," International Journal of Recent Trends in Engineering, vol. 2, no. 5, November 2009.

[9] M. Suetake and I. N. Silva, "Embedded DSP-Based Compact Fuzzy System and Its Application for Induction-Motor V/f Speed Control," IEEE Transactions on Industrial Electronics vol. 58, no. 3, March 2011.

[10] G. Godena and M. Colnaric, "Exception Handling for PLC-Based Process Control Software," Microprocessors and Microsystems, vol. 24, pp. 407-414, 2000.

[11] F. J. Lin and P. H. Chou, "Adaptive Control of Two-axis Motion Control System Using Interval Type-2 Fuzzy Neural Network," IEEE Trans. Inst. Elect., vol. 56, no. 1, January 2009.

[12] E. Ye_sil, M. G“uzelkaya, and I. Eksin, "Self-Tuning Fuzzy PID-type Load-Frequency Controller," Electrical Conversion and management, vol. 45, no. 3, pp. 377-390, 2004.

[13] R. Arulmozhiyal and K. Baskaran, "Space Vector Pulse Width Modulation Based Speed Control of Induction Motor Using Fuzzy PI Controller," International Journal of Computer and Electrical Engineering, ISSN 1793-8198, no. 1, pp. 98-103, Number 1, 2009.

[14] H. P. Huang, M. L. Roan, and J. C. Jeng, "On-line Adaptive Tuning for PID Controllers," IEEE Proc.-Control Theory Appl., vol. 149, no 1, pp. 60-67, 2002.

[16] I. Eksin, M. G“uzelkaya, and F. G“urleyen, "A new Methodology for Deriving The rulebase of a Luzzy Logic Controller with A new Internal Structure," Engineering Applications of Artificial Intelligence, vol. 14, no. 5, pp. 617-628, 2001.

[17] L. Reznik"Fuzzy Controllers," British Library Cataloguing in Publication Data ISBN 0 750634294.

[18] J. X. Xu, C. C. Hang, and C. Liu, "Parallel Structure and Tuning of a Fuzzy PID Controller," Automatica, vol. 36, pp. 673-684, 2000.

[19] H. M. Khalil and M. El-Bardini, "Implementation of Speed Controller for Rotary Hydraulic Motor Based on LS-SVM," Expert Systems with Applications, vol. 38, pp. 14249-14256, 2011.

[20] J. X. Deng, Z. 1. Zhang, and H. ming, "Simulation of Synchronous Excitation Controller Based on Fuzzy-PID Control,” Relay, vol. 35, no. 19, pp. 13-15, 21, 1 Oct., 2007.

[21] T. H. cheng, L. Z. xin, W. Z. tao, Z. X. qing, and Su, Yi, “a Fuzzy PID Control System Electric," Machines and Control, vol. 9, no. 2, pp. 136-138, March 2005.

[22] Zulfatman and M. F. Rahmat, "Application of Self-tuning Fuzzy PID Controller on Industrial Hydraulic Actuator Using Systems Identification Approach," International Journal on Smart Sensing and Intelligent Systems, vol. 2, no. 2, June 2009.

Journal of Engineering Sciences, Assiut University, Faculty of Engineering, Vol. 42, No. 1, January, 2014, E-mail address: jes@aun.edu.eg 
O. Awida et al., Practical implementation of fuzzy controller for controlling the CNC spindle motor using PLC, pp.180 - 198

\section{[1] Appendix}

The first page of fuzzy program ladder

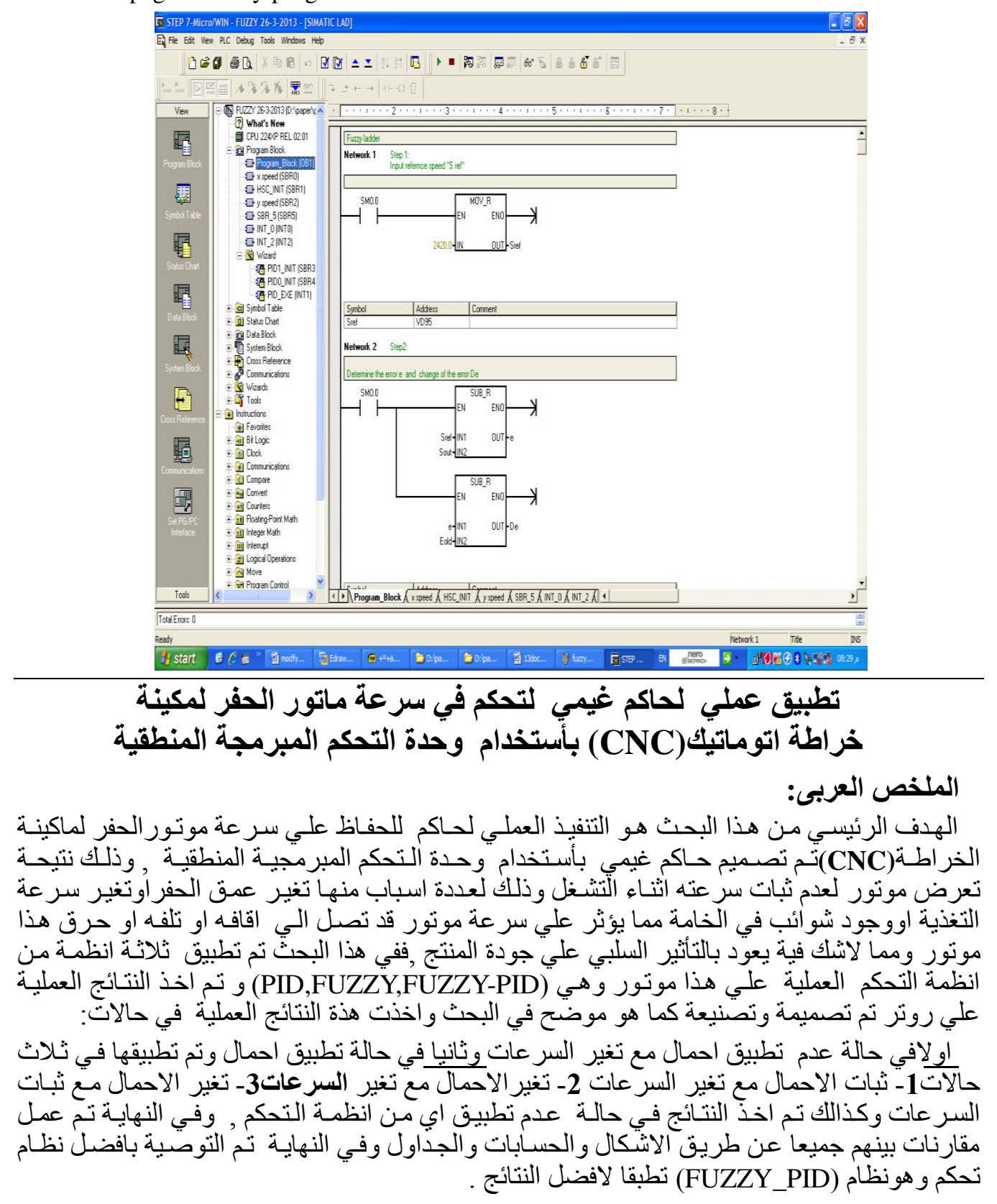

Journal of Engineering Sciences, Assiut University, Faculty of Engineering, Vol. 42, No. 1, January, 2014, E-mail address: jes@aun.edu.eg 